\title{
Investigating the Effect of Mesenchymal Stem Cells on Peripheral Nerve Repair with Quantitative Methods
}

\author{
Bülent Ayas ${ }^{1}$, Pınar Naile Gürgör ${ }^{2}$, Züleyha Erişgin ${ }^{3}$, Mehmet Çifci ${ }^{4}$ \\ ${ }^{1}$ Ondokuz Mayıs University, Medical Faculty, Department of Histology and Embryology, Samsun, Turkey \\ ${ }^{2}$ Ordu University, Medical Faculty, Department of Histology and Embryology, Ordu, Turkey \\ ${ }^{3}$ Giresun University, Medical Faculty, Department of Histology and Embryology, Giresun, Turkey \\ ${ }^{4}$ Plastic, Reconstructive and Aesthetic Surgery Specialist, Private Physician, Ataköy-İstanbul, Turkey
}

Received: 28 February 2019, Accepted: 12 April 2020, Published online: 30 April 2020

(C) Ordu University Institute of Health Sciences, Turkey, 2020

\begin{abstract}
Objective: The aim was to research the possible effects of bone marrow stromal cells on the effective method for peripheral nerve injuries of end-in-end repair for sciatic nerves using quantitative histologic methods.

Methods: Five adult male New Zealand rabbits had both sciatic nerves cut and then the end-in-end repair technique performed. Then while nothing was administered to the left side, the right side had autologous mesenchymal stem cell injection from previously cultured material administered. Four weeks later the repair area was removed, and sections were stained with S100 and CD31 antibodies. Stained sections were investigated for Schwann cells and vessels. Evaluations of the left and right sides were made by comparing their Schwann cell density and vessel density determined by estimating their volume fractions, separately.

Results: The repair areas on both sides showed no significant differences for the degree of immunoreactivity for S100 and CD31 ( $\mathrm{p}=0.003)$. But the volume fractions of Schwann cells and vessels within the repair areas were found to be increased for the cell-treated nerves, but statistically there was no difference for vessels $(\mathrm{p}=0.073)$.
\end{abstract}

Conclusion: These results support the findings already reported in the literature, that increased Schwann cell density will probably promote regeneration of the peripheral nerve.

Key words: Mesenchymal stem cells, peripheral nerve regeneration, end-in-end repair, volume fraction

Suggested Citation: Ayas B, Gurgor PN, Erisgin Z, Ciftci M. Investigating the Effect of Mesenchymal Stem Cells on Peripheral Nerve Repair with Quantitative Methods. Middle Black Sea Journal of Health Science, 2020; 6(1):65-69.

\section{Address for correspondence/reprints:}

Pınar Naile Gürgör

Telephone number: +90 (505) 2265200 - 5343

ORCID-ID 0000-0002-4154-4675

E-mail: pinarng@ @otmail.com

DOI: $10.19127 / \mathrm{mbsjohs.696163}$

\section{Introduction}

Schwann cells (SC) are an element of the peripheral nervous system that wraps nerve fibers. These cells are responsible for synthesis and maintenance of myelin. At the same time, they have important roles in nerve regeneration. They synthesize bioactive molecules as a result of nerve injury ensuring formation of more cells in the regenerating area and support axon regeneration (Ishikawa et al., 2009). Using these features, experimental research has studied the effects of SC on peripheral nerve injuries; however, use is limited due to difficulties with purification and proliferation. 
As a result, researchers have searched for other cellular resources that can be easily accessed and proliferated. One of these resources is bone marrow.

Bone marrow stromal cells are multipotential mesenchymal stem cells with the ability to transform into different cell types in appropriate conditions. One of the cells they can differentiate to is SC. Studies have shown that SC differentiated from bone marrow stem cells has great potential for induction of peripheral nerve regeneration (Tohill et al., 2004; Dezawa, 2002; Choi et al., 2005; Fernandes et al., 2008; Mahay et al., 2008). Additionally, bone marrow cells ensure production of many trophic factors and were shown to induce angiogenesis in areas of administration (Fernandes et al., 2008; Orlic et al., 2001; Perin et al., 2003).

The end-in-end nerve repair method (Siemionow et al., 2002) is one of the peripheral nerve repair techniques. This repair method has many positive features. It prevents axons from escaping the repair line, ensures accumulation of neurotrophic factors in the environment, prevents surrounding scar tissue from entering the regeneration area and reduces neuroma formation. In our study, noting the potential of bone marrow mesenchymal stem cells (MSC) we researched the effect on nerve regeneration.

\section{Methods}

Five adult white New Zealand rabbits weighing between 2500-3000 g were used in the study. Surgical procedures and care of animals were performed at Ondokuz Mayis University Surgical Research and Application Center.

\section{Obtaining mesenchymal stem cells}

Before performing surgical procedures on animals, the bone marrow retrieval process was completed. With an injector mounted on a special device, bone marrow aspiration was performed from the right crista iliaca. Aspirate with 3-6 cc volume obtained from each animal was placed in special cell culture medium under sterile conditions. The aspirates were preserved in the medium at $+4{ }^{\circ} \mathrm{C}$ and sent to a special facility (ATİ Technology Center, Trabzon, Turkey) to obtain MSC.

The obtained bone marrow aspirates were mixed with MSC production medium (Dulbecco's Modified Eagle Medium [DMEM], Fetal Bovine Serum [FBS] ((HyClone, Logan, UT, USA)), antibiotic [penicillin]) and centrifuged two times (2000 rpm, 5 minutes). The supernatant was obtained and suspended in cell pellet production medium. Mononuclear cell counts were performed, and certain numbers were transferred to the cell culture medium and cultured in an incubator at $37^{\circ} \mathrm{C}$ in $5 \% \mathrm{CO}_{2}$, and 95\% relative humidity. MSC forming confluence were removed for the trypsinization procedure, cell counts were performed and cultured in the same production medium to create advanced passages. When completing quality control tests (Okarma et al., 1992), some of the passage cells were used in experiments and the remaining section were placed in cryopreservation (Im et al., 2001; Kernan et al., 1987).

MSCs were delivered nearly two weeks later and the surgical procedure was performed.

\section{Surgical procedure}

The study was performed on the right and left sciatic nerves. The left side was assessed as the control group, while the right side had experimental procedures performed. For this, animals had vertical incision of both sciatic nerves. The proximal section of the epineurium was sutured to the distal section of the epineurium with the end-in-end repair method. Thus, a $5 \mathrm{~mm}$ long epineural tube was created. The cultured autologous mesenchymal stem cells were injected into the epineural tube for sciatic nerve repair only on the right side. The left side had no procedure performed within the tube.

Four weeks after the procedure, the repair area was removed on both sides and fixed in formalin. After routine histologic monitoring procedures, tissues submerged in paraffin had 10 sections obtained with nearly $6 \mu \mathrm{m}$ thickness with systematic random sampling. The sections were placed on poly l-lysine covered slides and labelled with S100 and CD31 antibodies (Cell Signaling Technology, Inc., Beverly, MA, USA) using the peroxidase technique and stained with DAB. Areas stained with S100 were accepted as Schwann cells while areas stained with CD31 were accepted as vessel. Evaluation between the right and left sides calculated the volume fractions for Schwann cell $\left(\mathrm{V}_{\mathrm{SC}}\right)$ and vessel densities $\left(\mathrm{V}_{\mathrm{D}}\right)$ and compared them (Howard and Reed, 1998). Comparison was completed by increasing magnification for areas on images. Sampling and point counts for the cross-section areas on the monitor were completed using two separate templates (Figure $1)$. 
A
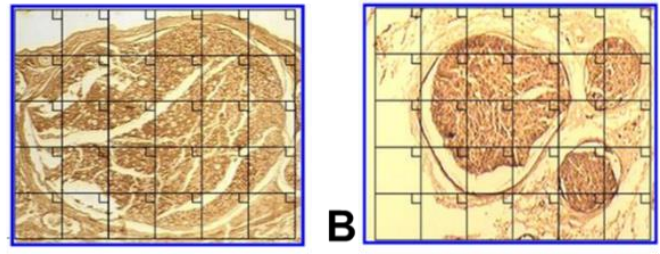

C
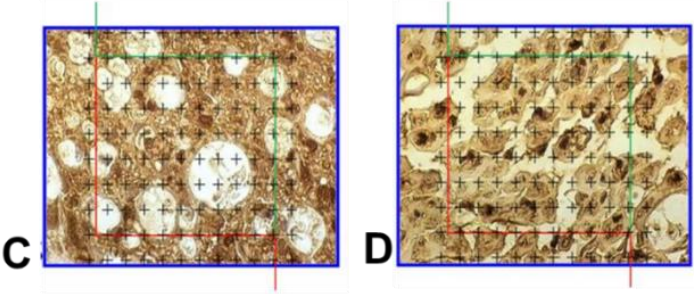

Figure 1. Calculations were completed in two steps. Firstly, areas were sampled at $4 \mathrm{x}$ magnification (A, B). Then points in the sampled areas were examined in order with counts at $60 \mathrm{x}$ magnification $(\mathrm{C}, \mathrm{D})$. $\mathrm{A}$ and $\mathrm{C}$ are areas with cells injected, B and D are from the control group.

\section{Statistical analysis}

As data had normal distribution, differences between the groups were evaluated using the paired ttest. Those with $p$ value lower than 0.05 were accepted as showing significant difference. Data are presented as mean \pm standard deviation (SD). All data analyses were conducted using the SPSS (Demo version 25.0, IBM Corp., Armonk, NY, USA) statistical software.

\section{Results}

In both repair areas, no difference was observed in terms of immunoreactivity in sections labelled with S100 and CD31. The data for volume fractions obtained from sections labelled with $\mathrm{S} 100$ are given in Table 1.

Table 1. Density of Schwann cells in right and left siatic nerve with mean \pm standard deviation (SD) and $p$ value

\begin{tabular}{ccc}
\hline $\begin{array}{c}\text { Animal no } \\
(\mathbf{n}=\mathbf{5})\end{array}$ & Right side & Left side \\
\hline $\mathbf{1}$ & 0.027 & 0.013 \\
$\mathbf{2}$ & 0.026 & 0.01 \\
$\mathbf{3}$ & 0.021 & 0.014 \\
$\mathbf{4}$ & 0.02 & 0.012 \\
$\mathbf{5}$ & 0.02 & 0.01 \\
\hline Mean \pm SD & $0.0228 \pm 0.0034$ & $0.0118 \pm 0.0018$ \\
$\boldsymbol{p}$ value & \multicolumn{3}{c}{$0.003 * *$} \\
$* * p<0.01$ & \multicolumn{3}{c}{}
\end{tabular}

As can be seen in Table 1, the SC density for the nerve with stem cells administered (right side) were much higher than sections without (up to two times more). In fact, according to these results there was a statistically significant difference found between the right repair area and left repair area in terms of cell density $\left(\mathrm{V}_{\mathrm{SC}}\right)(\mathrm{p}=0.003)$.

Table 2. Vessel density $\left(\mathrm{V}_{\mathrm{D}}\right)$ in right and left sciatic nerve with mean \pm standard deviation (SD) and $p$ value

\begin{tabular}{ccc}
\hline $\begin{array}{c}\text { Animal no } \\
(\mathbf{n = 5})\end{array}$ & Right side & Left side \\
\hline $\mathbf{1}$ & 0.0061 & 0.0028 \\
$\mathbf{2}$ & 0.0031 & 0.0025 \\
$\mathbf{3}$ & 0.0029 & 0.0028 \\
$\mathbf{4}$ & 0.0049 & 0.0032 \\
$\mathbf{5}$ & 0.0048 & 0.0038 \\
\hline Mean \pm SD & $0.0043 \pm 0.0014$ & $0.0030 \pm 0.0005$ \\
$\boldsymbol{p}$ value & \multicolumn{2}{c}{0.073} \\
\hline
\end{tabular}

When the data in Table 2 are examined, there were differences in vessel density in the area with stem cell injected compared to the control group for some animals. In fact, in animals numbered 1 and 4, an excess amount of vascularization was observed in the right repair area compared to the left side. However, considering the mean in the groups, there was no significant difference in statistical terms $(\mathrm{p}=0.073)$.

\section{Discussion}

The use of bone marrow-sourced stem cells for peripheral nerve injury has become more common in the last decade. Advantages of these cells include the ability to differentiate in many ways and being easy to access. Their importance for nerve repair is due to transforming into Schwann-like cells or supporting axonal growth by ensuring proliferation of Schwann cells in the environment. At the same time, they are thought to regulate release of neurotrophic factors and receptors in the repair area. Additionally, they are proposed to ensure secretion of a range of cytokines and growth factors increasing angiogenesis. In this study, these features of mesenchymal stem cells were combined with a new nerve repair technique (Siemionow et al., 2002) and we quantitatively researched the effects on the repair area. The results of the study are in parallel with the results of other studies.

A study by Fernandes et al. (2008) used venous graft for nerve repair in a study of rats. The group using graft were injected with supplementary autologous bone marrow cells. The cellsupplemented group obtained better results compared to the group with autologous nerve graft and they reported the vessel density in the stem cell group was significantly increased compared to the other groups especially. Dezawa et al. (2001) used bone marrowsourced mesenchymal stem cells for peripheral nerve 
repair and showed these cells transformed into Schwann-like cells using S100 and p75 markers. Cuevas et al. (2002) injected previously-labelled adult bone marrow stem cells in peripheral nerve incisions and identified that a portion of these labelled cells differentiated into Schwann cells. A study of rats by Wang et al. (2009) injected mesenchymal stem cells in nerve grafts with length of $10 \mathrm{~mm}$. Compared with the control group, they identified pronounced axon growth and many Schwann cells in stem cell grafts on the $7^{\text {th }}$ and $14^{\text {th }}$ days. Choi et al. (2005) in studies using vein grafts added cultured bone marrow to the grafts and observed these cells transformed into Schwann-like cells. They obtained better outcomes in the repair area compared to the control group. Tohill et al. (2004) used three different cell sources and applied them separately to $1 \mathrm{~cm}$ nerve graft used in the sciatic nerve of rats. These were cultured Schwann cells, undifferentiated bone marrow cells and differentiated bone marrow cells. They determined the regeneration distance using S100 antibody. Compared to the control group, they observed clear axon growth and amelioration in the three groups. Undifferentiated bone marrow cells differentiated with cellular and humoral effects in the graft area and they considered S100 specific to glial cells were synthesized. Zhang et al. (2004) injected undifferentiated mesenchymal cells obtained from bone marrow into $10 \mathrm{~mm}$ nerve grafts. These previously-labelled cells were identified to synthesize S100, GFAP and p75 reflecting Schwann cell properties.

All these studies show that the presence and amount of Schwann cells in the nerve repair area is important for vascularization of the area and more rapid and quality regeneration. In this sense cultured mesenchymal stem cells provided notable results for peripheral nerve repair. However, the approach to nerve injury repair possesses separate importance in addition to cellular administration. The elements that should be provided by repair methods include accumulation of growth factors and cytokines in the repair area, prevention of foreign object reactions, prevention of surrounding scar tissue entering the repair area, preventing axons from leaving the repair line and thus reducing neuroma formation. The repair method in our study ensures these situations, in addition to allowing accumulation of injected stem cells in the area. In fact, the higher S100 and CD31 positive areas compared to the control group appear to confirm this situation. When we compare our parameters with other studies, no quantitative data was given for comparison. The amounts of Schwann cells and vessels in the repair area in this study were revealed comparatively with the control group.

It is clear that these types of studies will continue in future years. Just as studies to be performed can use different stem cell sources with our applied repair method, the inclusion of different healing weeks will expand these studies.

Acknowledgments: The autors would like to thank Dr. Yeliz KAŞKO ARICI (Biostastics and Informatic Unit, Faculty of Medicine, Ordu University) for her help with the statistical analyses of this manuscript.

In memory of our esteemed late mentor Prof. Dr. Adnan KORKMAZ who worked with us since the beginning of the project.

Ethics Committee Approval: The study was carried out in accordance with ethical principles by obtaining the necessary permissions within the scope of the project numbered $\mathrm{T} 573$ at Ondokuz May1s University.

Peer-review: Externally peer-reviewed.

Author Contributions: Concept-BA, AK, PNG; Design-BA, AK, PNG; Supervision-BA, AK, PNG; Funding- BA; Materials- BA, MC; Data Collection/Data Process- PNG, BA, ZE, MC; Analyze or Comment- PNG, BA; Literature Scanning- PNG, BA; Writer of Paper-PNG, BA; Critical Review-PNG.

Conflict of Interest: No conflict of interest was declared by the authors.

Financial Disclosure: This study was supported by the Project Management office of Ondokuz Mayis University (Project No. T573)

\section{References}

Choi BH, Zhu SJ, Kim BY, Huh JY, Lee SH, Jung JH. Transplantation of cultured bone marrow stromal cells to improve peripheral nerve regeneration. Int J Oral Maxillofac Surg. 2005; 34(5): 537-542.

Cuevas P, Carceller F, Dujovny M, Garcia-Gómez I, Cuevas B, González-Corrochano R, DiazGonzález D, Reimers D. Peripheral nerve regeneration by bone marrow stromal cells. Neurol Res. 2002; 24(7): 634-8.

Dezawa M, Takahashi I, Esaki M, Takano M, Sawada $\mathrm{H}$. Sciatic nerve regeneration in rats induced by transplantation of in vitro differentiated bonemarrow stromal cells. Euro J Neuros. 2001; 14(11): 1771-1776. 
Dezawa M. Central and peripheral nerve regeneration by transplantation of Schwann cells and transdifferentiated bone marrow stromal cells. Anatomical Science International. 2002; 77(1): 12-25.

Fernandes M, Valente SG, Fernandes MJS, Félix EP, Mazzacoratti Mda G, Scerni DA, dos Santos JB, Leite VM, Faloppa F. Bone marrow cells are able to increase vessels number during repair of sciatic nerve lesion. J Neurosc Metods. 2008; 170(1): 1624.

Howard CV and Reed MG. Unbiased Stereology, Three-Dimensional Measurement in Microscopy. First edition. BIOS scientific publishers. 1998.

Im Gl, Kim DY, Shin JH, Hyun CW, Cho WH. Repair of cartilage defect in the rabbit with cultured mesenchymal stem cells from bone marrow. J Bone Joint Surg Br. 2001; 83(2): 289-294.

Ishikawa N, Suzuki Y, Dezawa M, Kataoka K, Ohta $\mathrm{M}$, Cho H, Ide C. Peripheral nerve regeneration by transplantation of BMSC-derived Schwann cells as chitosan gel sponge scaffolds. J Biomed Mater Res A. 2009; 89(4): 1118-1124.

Kernan NA, Flomenberg N, Dupont B, O'Reilly RJ. Graft rejection in recipients of T-cell-depleted HLA-nonidentical marrow transplants for leukemia. Identification of host-derived antidonor allocytotoxic $\mathrm{T}$ lymphocytes. Transplantation. 1987; 43(6): 842-847.

Mahay D, Terenghi G, Shawcross SG. Schwann cell mediated trophic effects by differentiated mesenchymal stem cells. Experimental Cell Res. 2008; 314(14): 2692-2701.

Okama T, Lebkowski J, Schain L, Harvey M. Tricot G, Srour E, Meyers WG, Burnett A, Sniecinski I, O'Reilly RJ. The AIS CELLector: A new technology for stem cell purification. Prog Clin Biol Res. 1992; 377: 487-502.

Orlic D, Kajstura J, Chimenti S. Jakoniuk I, Anderson SM, Li B, Pickel J, McKay R, Nadal-Ginard B, Bodine DM, Leri A, Anversa P. Bone marrow cells regenerate infarcted myocardium. Nature. 2001; 410(6829): 701-705.

Perin EC, Dohmann HF, Brojevic R, Silva SA, Sousa AL, Mesquita CT, Rossi MI, Carvalho AC, Dutra HS, Dohmann HJ, Silva GV, Belém L, Vivacqua R, Rangel FO, Esporcatte R, Geng YJ, Vaughn WK, Assad JA, Mesquita ET, Willerson JT. Transendocardial, autologous bone marrow cell transplantation for severe, chronic ischemic heart failure. Circulation. 2003; 107(18): 2294-2302.
Siemionow M, Tetik C, Ozer K, Ayhan S, Siemionow $\mathrm{K}$, Browne E. Epineural sleeve neurrorrhaphy: surgical technique and functional resultspreliminary report. Annals of Plastic Surgery. 2002; 48(3): 281-285.

Tohill M, Mantovani C, Wiberg M, Terenghi G. Rat bone marrow mesenchymal stem cells express glial markers and stimulate nerve regeneration. Neuroscience Letters. 2004; 362(3): 200-203.

Wang J, Ding F, Gu Y, Liu J, Gu X. Bone marrow mesenchymal stem cells promote cell proliferation and neurotrophic function of Schwann cells in vitro and in vivo. Brain Res. 2009; 1262: 7-15.

Zhang P, He X, Liu K, Zhao F, Fu Z, Zhang D, Zhang Q, Jiang B. Bone marrow stromal cells differentiated into functional Schwann cells in injured rats sciatic nerve. Artif. Cells Blood Substit. Immobil. Biotechnol. 2004; 32(4): 509518. 